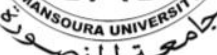

MANSOURA UNIVERSITY

FACULTY OF ARTS

\title{
ANTI-IMPERIAL RUMBLING IN JOSEPH CONRAD'S HEART OF DARKNESS
}

\section{By \\ Ph.D.Nouh Ibrahim Saleh Alguzo,}

Associate Professor of English

Al-Imam Muhammad Ibn Saud Islamic University

Al-Ahsa Campus

Department of English -Saudi Arabia

Journal of The Faculty of Arts- Mansoura University

$64^{\text {th }}$ ISSUE- JAN. 2019 


\section{ANTI-IMPERIAL RUMBLING IN JOSEPH CONRAD'S HEART OF DARKNESS Ph.D.Nouh Ibrahim Saleh Alguzo,}

\section{Abstract}

This study opposes those critics who read Joseph Conrad's Heart of Darkness as a work that explores human evil while overlooking imperialism as a cause of this evil. Conrad uses symbolism to criticize the atrocity and inhumanity of imperialists in Africa while at the same time sympathizes with the natives whom he presents as victims of the greediness of those imperialists. He announces that the Europeans are not emissaries of civilization, but of destruction and poverty. He also condemns the corruption and hypocrisy of the Europeans who claim that their presence in the Congo is for humanitarian purposes, while in reality stealing the resources of the land. Therefore, Conrad aims at uncovering the deceptive practices of imperialists through his novella rather than justify imperialism as some critics may claim.

Keywords: Imperialism, Europeans, hypocrisy, Africa, natives.

$$
\begin{aligned}
& \text { تعارض هذه الدراستة هؤلاء النقاد الذين يترؤون رواية قلب الظلمة لجوزيف كونراد كعدل بيتكثف الشر الإنساني ويتجاهلون الحديث عن الإمبريالية }
\end{aligned}
$$

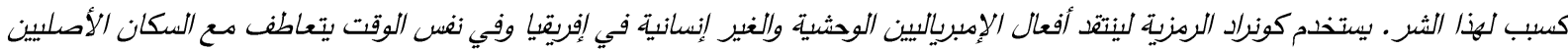

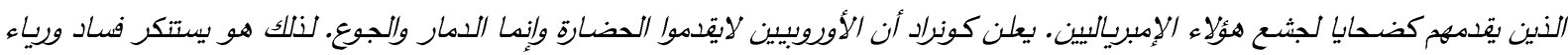

$$
\begin{aligned}
& \text { الأوروبين الذين ياعوون أن وجودهم في الكونغو من أجل أهداف إنسانية وبنيا في الحقيقية يقومون بسرقة موارد البلاد. وبالتالي يهدف كونيراد الأن }
\end{aligned}
$$

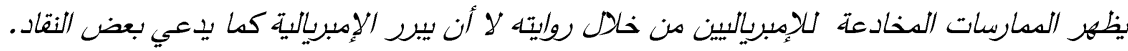

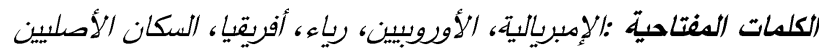

Heart of Darkness recounts the horrors of the European imperial enterprise in the late nineteenth century. The story is in part based on Joseph Conrad's aboard the steamship Roi des Belges on the Congo River in 1890. Conrad introduces himself as a historian who exposes the hypocrisy of the Europeans and the claim that their project in the Congo is noble and moral. He believes that "Fiction is history, human history, or it is nothing', that a novelist is a historian, the preserver, the keeper, the expounder, of human experience"” (Raskin 115). Throughout his experience in the Congo, Conrad discloses the secrets of imperialism that many literary critics neglected. Jonah Raskin notes, "literary critics have neglected imperialism and have transformed the novella into a timeless myth about the exploration of the human soul and the metaphysical power of evil" (113). Hunt Hawkins also argues that "Conrad's general attitude toward imperialism is complicated because he usually treats it case by case" (293). Throughout this paper, I contend that imperialism is the main concern of Heart of Darkness in which Conrad expresses his hatred of the European colonial mission in the Congo.
The second narrator in Heart of Darkness, Marlow, who stands for Conrad himself, struggles hardly to reveal the brutalities of the Europeans that he witnessed in the Congo. Conrad introduces Marlow as an emissary of truth as Chinua Achebe argues, "Marlow comes through to us not only as a witness of truth, but one holding those advanced and humane views appropriate to the English liberal tradition which required all Englishmen of decency to be deeply shocked by atrocities in Bulgaria or the Congo of King Leopold of the Belgians or whatever" (7). The Europeans claim that they go to Africa for humanitarian reasons: to educate the people there and make their life better. They announce that "[They] had got a heavenly mission to civilize [the Africans]" (Conrad 8). However, Marlow announces that the only reason for the Europeans to invade Africa was economic. Therefore, we come to realize that the expansion of imperialism is based upon the myth of helping the poor and the oppressed.

Marlow introduces an analogy between the Romans invasion of Britain and the Europeans invasion of the Congo. He says: 
'I was thinking of very old times, when the Romans first came here, nineteen hundred years ago - the other day.... Light came out of this river since-you say Knights? Yes; but it is like a running blaze on a plain, like a ash of lightning in the clouds. We live in the flicker-may it last as long as the old earth keeps rolling! But darkness was here yesterday.(Conrad 5)

Marlow is highly critical of the Europeans by suggesting that they repeat the barbarism of the historical Roman Empire. He attributes the destruction of societies to the savage practices of those who are obsessed with asserting power over the other. Marlow links imperialism to darkness and death by proposing that conquering other people violates their cultures. Jonah Raskin says: "One of the ironies of Heart of Darkness is that the modern colonialist repeats the historical experience of the Roman empirebuilder, though his exile and death is enacted in the Congo" (118). Paul Wake also comments, "Heart of Darkness ... is a novel that is preoccupied with death: its 118 pages are littered with representations of the dying and the dead, and death is referred to on almost every second page" (36). Therefore, darkness symbolizes the evil practices of the Belgians in the Congo and their bloody actions to take the resources of the land from its people by force.

Just as Conrad who took command of a steamship in the Congo in 1890, Marlow takes a job with the Belgian Company that trades in the Congo unknowing about the brutality of the Company members. John Tessitore explains that "literary criticism has often approached Marlow as Conrad's alter ego" (602). The journey of Marlow into the Congo makes him realize man's inhumanity to man and the inner darkness of the self. Marlow criticizes those who invade other cultures only because people have different complexion when he says:
The conquest of the earth, which mostly means the taking it away from those who have a different complexion or slightly flatter noses than ourselves, is not a pretty thing when you look into it too much. What redeems it is the idea only. An idea at the back of it; not a sentimental pretence but an idea; and an unselfish belief in the idea-something you can set up, and bow down before, and offer a sacrifice to. ...' (Conrad 6-7) Conrad is undoubtedly critical of the imperial mission of conquering other nations and this refutes the belief of some critics, like Chinua Achebe, who claim that "Conrad was a bloody racist" (9). Achebe harshly criticizes Conrad:

I would not call that man an artist, for example, who composes an eloquent instigation to one people to fall upon another and destroy them. No matter how striking his imagery or how beautiful his cadences fall, such a man is no more a great artist than another may be called a priest who reads the mass backwards or a physician who poisons his patients. (9)

Through reading Heart of Darkness, we come to apprehend that Conrad does not justify the imperial enterprise in Africa nor exploiting the people there. On the contrary, Conrad sympathizes with the Congolese people who are forced into the service of the Belgian Company and treated as less than human. Conrad suggests that imperialism should come to an end and that the Europeans have no right to invade other nations through disclosing the secrets of this bloody project.

The Doctor who examines Marlow before going to the Congo represents an example of the hypocrisy of the Europeans. The dialogue between Marlow and the Doctor goes as such:

'I always ask leave, in the interests of science, to measure the crania of those going out there,' he said. 'And when they come back, too?' I asked. 'Oh, I never see them,' he remarked; 'and, 
moreover, the changes take place inside, you know.' He smiled, as if at some quiet joke. 'So you are going out there. Famous. Interesting, too.' He gave me a searching glance, and made another note. 'Ever any madness in your family?' he asked, in a matter-offact tone. I felt very annoyed. 'Is that question in the interests of science, too?' 'It would be,' he said, without taking notice of my irritation, 'interesting for science to watch the mental changes of individuals, on the spot' (Conrad 14)

The Doctor never cares about those people who go to Africa as individuals who have identities, but as figures to support his scientific experiments. $\mathrm{He}$ thrives to examine the mental changes and the madness of individuals who work for the Company. Jonah Raskin comments: "It is a world in which Belgians and Africans are both victims and victimizers, corrupting and corrupted" (124). The African helmsman, who the Europeans exploit as a tool to steer the steamship, is another character that shows the hypocrisy of the imperialists. Marlow talks about the helmsman as an instrument: "He had done some- thing, he had steered; for months I had him at my back - a help - an instrument. It was a kind of partnership. He steered for me-I had to look after him, I worried about his deficiencies, and thus a subtle bond had been created, of which I only became aware when it was suddenly broken" (Conrad 75). Marlow never refers to the helmsman, who is detribalized by imperialism, as a human being who has identity or as equal to the Europeans, but as an instrument that was used to steer. In fact, the murder of the helmsman did not mean anything to the colonial Belgians other than losing helpful instrument that was used to steer the steamship. Therefore, we can say that Heart of Darkness explains "the way humans can submit themselves to their darkest impulses" (Lara 138). The Congo, thus, represents a place where individuals, who are removed from their cultures, lose self-restraint and humanity.

Conrad announces that "your strength is just an accident arising from the weakness of others" (6). This quotation implies that the Africans submitted themselves to the dark impulses of the Belgians and accepted to be treated as other. When the predecessor of Marlow in the Congo was killed, all the villagers departed the village because of their belief that the European was a supernatural creature and that curse would befall upon them. Marlow tells the story of the death of his predecessor:

I couldn't let it rest, though; but when an opportunity offered at last to meet my predecessor, the grass growing through his ribs was tall enough to hide his bones. They were all there. The supernatural being had not been touched after he fell. And the village was deserted, the huts gaped black, rotting, all askew within the fallen enclosures. (Conrad 10)

No doubt that this quotation suggests the inferiority complex of the natives and their ignorance. The natives believe that touching the body of the European is a great sin that would make them get punished by supernatural powers. Hunt Hawkins notes, "In the political aspect of the story, [Conrad] was making an appeal to the values of his audience so that they might censure the atrocities in the Congo (288). Conrad seems to be aware that the colonial rule had great impact on the life of Africans that resulted in anticolonial resistance. Moreover, he implies that the colonial project is responsible for all the brutalities and murders that happen in Africa.

As all other Europeans, Marlow finds in working for the Company a source of income as well as engaging himself in the alleged humanitarian cause in the Congo. However, soon after his first visit to the offices of the Company in Brussels, he comes to realize that there was something menacing in the atmosphere. Marlow 
describes his first visit to the Company: "I began to feel slightly uneasy. You know I am not used to such ceremonies, and there was something ominous in the atmosphere. It was just as though I had been let into some conspiracy - I don't knowsomething not quite right; and I was glad to get out" (Conrad 12). He also says: "I ventured to hint that the Company was run for profit" (15). The description of the cause of the Europeans as some kind of "conspiracy" represents clear evidence that Marlow disapproves of the imperialist cause of the Europeans. This contradicts the claim of Hunt Hawkins who argues that Conrad justifies imperialism in Heart of Darkness. Hawkins says: "[Conrad] appears to justify British imperialism on grounds that it is 'efficient' and conducted according to some unspecified 'idea"' (286). However, the one who reads Heart of Darkness will realize that Conrad never justifies imperialism or the invasion of other countries. On the contrary, we find out that Conrad parodies the Europeans who are introduced as hypocrites and greedy.

The most interesting thing about Conrad in the novella is his use of symbolism to criticize the imperial enterprise in the Congo rather than critiquing the imperialists directly. Therefore, he uses the word "pilgrims" to refer to the colonial administrators to show that their project is unholy and immoral. Evelyn Cobley comments, "the 'pilgrims' are dull because they have succumbed to a routinized life devoid of any meaningful purpose" (189). Cobley adds: "The 'pilgrims' hypocritically conceal 'the banality of their evil' under an 'institutional formalism' that Marlow condemns for its petty criminality and hypocrisy" (191-192). Conrad is filled with pity for the victims of the immoral purpose of colonialism. Therefore, Marlow, who is the voice of Conrad, introduces the natives as victims when he says: "It was the same kind of ominous voice; but these men could by no stretch of imagination be called enemies.
They were called criminals, and the outraged law, like the bursting shells, had come to them, an insoluble mystery from the sea" (20). However, in order to justify the killing of the Congolese people and stealing the resources of their country through claiming that they trade in the Congo, the Belgians accuse them of being enemies and criminals.

Conrad suggests that the Europeans transform into savages when they are removed away from their culture. The image of the Europeans committing suicide in the novella implies the horrible consequences of imperialism on the Europeans and natives alike. Marlow tells the story of the Swede who killed himself: "The other day I took up a man who hanged himself on the road. He was a Swede, too.' 'Hanged himself! Why, in God's name?' I cried. He kept on looking out watchfully. 'Who knows? The sun too much for him, or the country perhaps" (Conrad 19). No doubt that the image of the Europeans committing suicide in the Congo implies their shock of the brutalities of the administrators of the Company. Richard Arneson argues: "The plot outline of Heart of Darkness appears to carry the message that we civilized humans are disposed to revert to barbarism when we are plucked away from the constraints of civilization and set down isolated in the wilderness" (426). This implies that the Europeans do not retain their humanity and moral attitudes when they are controlled by the dark impulses of the Company administrators who are willing exert power over anyone to collect ivory.

The elegant lifestyle of the administrators of the Company discloses their alleged holy mission in the Congo that they use as a means to better their conditions while at the same time ignoring the natives who are dying of hunger. The life of imperialists is described as following:

'I didn't want any more loitering in the shade, and I made haste towards the station. When near the buildings I met a white man, in such an 
unexpected elegance of get-up that in the first moment I took him for a sort of vision. I saw a high starched collar, white cuffs, a light alpaca jacket, snowy trousers, a clean necktie, and varnished boots. No hat. Hair parted, brushed, oiled, under a green-lined parasol held in a big white hand. He was amazing, and had a penholder behind his ear. (Conrad 23)

This image of the Europeans differs from the image of the natives who suffer from ill treatment and overwork. Marlow says about the natives that "they were dying slowly-it was very clear. They were not enemies, they were ... nothing but black shadows of disease and starvation, lying confusedly in the greenish gloom" (Conrad 22). The claim of the Europeans that the natives are prehistoric and uneducated is only to justify the use of power over them. However, the contrastive image of the Europeans and the natives aims to make the readers sympathize with those who are oppressed and suppressed. While Marlow is moving into the heart of darkness exploring the evil purposes of imperialists who force the natives into their service, he presents those imperialists as worshippers of ivory:

They wandered here and there with their absurd long staves in their hands, like a lot of faithless pilgrims bewitched inside a rot-ten fence. The word 'ivory' rang in the air, was whispered, was sighed. You would think they were praying to it. A taint of imbecile rapacity blew through it all, like a whiff from some corpse. By Jove! I've never seen anything so unreal in my life. (Conrad 32)

This suggests that the Europeans have no right to invade the Congo on the claim that they are virtuous and righteous. After the invasion of the Congo "you would think there was not a single tusk left either above or below the ground in the whole country" (Conrad 70). By introducing the Europeans as worshippers of ivory, Marlow attempts to deconstruct the stereotypical image about them as supernatural, civilized and holy. To prove this, Marlow refers to the phony lifestyle of the manager of the Company who tries to take advantage of the illness of Kurtz, the chief of the inner station, to replace him.

Unlike other Europeans who take ivory on the claim of trade, Kurtz follows a policy of extermination and takes ivory by force. The Europeans consider Kurtz as the most remarkable man because he can collect ivory more than all other Europeans together; at the same time, Kurtz is an eloquent creature who uses the power of words to convince the natives collect ivory for him or get punishable by death. Marlow talks about Kurtz:

Hadn't I been told in all the tones of jealousy and admiration that he had collected, bartered, swindled, or stolen more ivory than all the other agents together? That was not the point. The point was in his being a gifted creature, and that of all his gifts the one that stood out preeminently, that carried with it a sense of real presence, was his ability to talk, his words - the gift of expression, the bewildering, the illuminating, the most exalted and the most contemptible, the pulsating stream of light, or the deceitful flow from the heart of an impenetrable darkness. (Conrad 69-70)

The experience of Marlow in the inner station teaches him better understanding of the life of the colonies through the honesty of the Kurtz. Kurtz disagrees with the "lenient" policy of other Europeans, and therefore "he had taken a high seat amongst the devils of the land" (Conrad 72). Regardless of the cruelty of Kurtz, he remains the only honest man among all Europeans and the one who exposes the real motive behind the presence of the Europeans in Africa. Achebe describes Africa as the opposite of Europe and civilization: "Heart of Darkness projects the image of Africa as "the other world," the antithesis of Europe and therefore of 
civilization, a place where man's vaunted intelligence and refinement are finally mocked by triumphant bestiality" (3). However, it would be true to say that the inhumanity of the Europeans and stealing the treasures of the land are the reasons that make Africa "the antitheses of Europe" as Achebe claims. Furthermore, the savage practices of the Europeans and killing the natives can never be described as civilized or cultured. Raskin notes that Marlow comes to know about the true life of the Europeans not in Europe but in Africa: "This experience, this discovery of exploitation, commercialism, and inhumanity which lay behind the progressive claims of empire builders, had a profound impact on his understanding of society. He came to believe that the true nature of European society was revealed in the colonies" (119). This reminds us with the doctor who examines the changes inside the minds of the supposed civilized Europeans and how they turn into savages who are willing to kill anyone for a small amount of ivory. Accordingly, Africa is the right place to get to know about the true identity of the Europeans where law is not enforced and savagery rules.

The time that Marlow arrives into the inner station represents moment of truth and self-knowledge. Marlow is shocked by the scene of the heads of natives on the top of poles who are charged of insurgence and disobedience. When the Russian disciple of Kurtz tells Marlow that these heads are the heads of rebels, Marlow is appalled:

I shocked him excessively by laughing.

Rebels! What would be the next definition I was to hear? There had been enemies, criminals, workers - and these were rebels. Those rebellious heads looked very subdued to me on their sticks. 'You don't know how such a life tries a man like Kurtz,' cried Kurtz's last disciple. 'Well, and you?' I said. 'I! I! I am a simple man. I have no great thoughts. I want nothing from anybody. (Conrad 88)
Kurtz has come to Africa with "thunder and lightning" (Conrad 84) and has already pronounced himself as god among the natives. He has plans to rule all over the land and would exterminate anyone who may interfere with him. Therefore, the manager confesses to Marlow that "Kurtz has done more harm than good to the Company ... Because the method is unsound" (Conrad 93). This unsound method means to openly steal the resources of the Congo rather than deceiving the natives on the claim of trade.

Regardless of the savage impulses of Kurtz, Marlow remains one of few characters who sympathize with Kurtz because he considers him victim of the European imperial project. Before arriving into the Congo, none of the Europeans including Kurtz knew about the secret world of the Company and their hidden plans there. John Tessitore argues, "In a very real sense, Kurtz had been driven by necessity to the Congo and away from everything he held dear" (32-33). Tessitore adds: "Kurtz is willing to subjugate and exploit the tribes of the interior just as all Europe is willing to take part in the gruesome rape and slaughter of the entire Congo" (39). Kurtz unknowingly gets involved into the imperial cause of the administrators of the Company who exploit the Europeans, who are "driven by necessity to the Congo", to collect ivory for them. Therefore, Marlow announces Kurtz as victim when he says: "The original Kurtz had been educated partly in England, and ... his sympathies were in the right place. His mother was half-English, his father was half-French. All Europe contributed to the making of Kurtz" (73). Marlow suggests that if there is someone responsible for the destruction of Africa, it would be Europe not Kurtz. Europe created Kurtz and introduced him to the world as civilized creature and then sent him to Africa to practice savagery there.

The death of Kurtz symbolizes the end of imperialism where someone gets to know about himself and the world around 
him. Marlow describes the dying Kurtz: "I saw the inconceivable mystery of a soul that knew no restraint, no faith, and no fear, yet struggling blindly with itself' (Conrad 101). Kurtz dies pronouncing his last words: "The horror! The horror!" (Conrad 105) where Marlow considers his death "a moment of triumph for the wilderness" (112). Kurtz attains knowledge about the deception and hypocrisy of the administrators of the Company on his deathbed. Hillis Miller announces that death represents moment of truth: "To say that the darkness is the end of all things is to identify the darkness with death, and to realize that the truth of the universe can only be recognized by those who have entered the realm of death" (31). Paul Wake also notes, "Death is the moment at which truth is allowed to appear and Kurtz's death is figured as a victory that allows him access to truth" (47). However, death can not be considered a moment of victory for Kurtz who dies in the wilderness away from his homeland and fiancée, but a moment of defeat where no one shows signs of grief for his death.

In conclusion, Heart of Darkness represents criticism of the imperial enterprise in Africa and the brutality of the Company administrators who mistreat the natives. Conrad suggests that there is no nation has the right to invade another, and therefore he parodies the alleged European humanitarian cause in Africa as a means to steal the resources of the land. In their quest for wealth in Africa, the Europeans, a way from their culture and homeland, are corrupted and their moral values are abandoned. As a result, Conrad recognizes the humanity of the natives by introducing them as victims of imperialism in contrast to the savagery and immorality of the imperialists.

\section{References}

- Achebe, Chinua. "An Image of Africa." Research in African Literatures 9.1 (1978): 1-15.

- Arneson, Richard J. "Marlow's Skepticism in Heart of Darkness." Ethics 94.3 (1984): 420-440.

- Cobley, Evelyn. Modernism and the Culture of Efficiency: Ideology and Fiction. Toronto: University of Toronto Press, 2009.

- Conrad, Joseph. Heart of Darkness. Beirut: York Press, 2011.

- Hawkins, Hunt. "Conrad's Critique of Imperialism in Heart of Darkness." PMLA 94.2 (1979): 286-299.

- Lara, Maria Pia. Narrating Evil: A Postmetaphysical Theory of Reflective Judgment. Ed. Amy Allen. Columbia: Columbia University Press, 2007.

- Miller, J. Hillis. Poets of Reality: Six Twentieth Century Writers. Cambridge, MA: The Belknap Press of Harvard University Press, 1966.

- Raskin, Jonah. "Imperialism: Conrad's Heart of Darkness." Journal of Contemporary History 2.2 (1967): 113131.

- Tessitore, John. "Freud, Conrad, and 'Heart of Darkness.'" College Literature 7.1 (1980): 30-40.

- Wake, Paul. Conrad's Marlow: Narrative and death in 'Youth', Heart of Darkness, Lord

- Jim and Chance. Manchester: Manchester University Press, 2007> 